\title{
The Determinants of Profitability of the Pharmaceutical Industry of Bangladesh: A Random Effect Analysis
}

\author{
Md. Shahidul Islam ${ }^{1} \&$ Muhammad Saifuddin Khan ${ }^{2}$ \\ ${ }^{1}$ Department of Banking and Insurance, University of Dhaka, Dhaka, Bangladesh \\ ${ }^{2}$ Department of Finance, Faculty of Business Studies, University of Dhaka, Dhaka, Bangladesh \\ Correspondence: Md. Shahidul Islam, Associate Professor, Department of Banking and Insurance, University of \\ Dhaka, Dhaka-1000, Bangladesh.
}

Received: February 24, 2019

Accepted: March 25, 2019

Online Published: April 2, 2019

doi:10.5430/ijfr.v10n2p68

URL: https://doi.org/10.5430/ijfr.v10n2p68

\begin{abstract}
The present study investigates the factors affecting the profitability of the pharmaceutical industry of Bangladesh. Using the data of 20 listed pharmaceutical companies fully functional in Bangladesh, we found both the firm specific and the macroeconomic specific variables affect the profitability of the companies. A panel dataset of 10 years starting from 2007 to 2016, we ran the random effect regression. The regression output depicts that among the firm specific variables, sales, operating income, operating cost, return on equity and total liabilities have significant effect on the profitability of the companies. We also found that the GDP growth rate and the rate of inflation among the macroeconomic variables have significant deterministic role on the profitability. The regression results followed by recommendations will be a great help to the policy makers both from inside and outside of the corporations.
\end{abstract}

Keywords: return on asset, return on equity, random effect

JEL Classification: G21, M41

\section{Introduction}

Pharmaceutical sector is one of the vibrant industries in Bangladesh that have huge contribution for the economic development of the country. The Drug Control Act, 1982 is one of the promulgating factors for the rapid growth of this sector. Also the professional knowledge, thoughts and innovative ideas of the pharmacists working in this sector are the key for the prosperity of this industry. At present, there are 231 pharmaceutical companies of which 150 are actively and continuously producing different types of drugs in Bangladesh. Bangladeshi pharmaceutical companies meet the 94 percent of the local demand of medicines. The market size of the local pharmaceutical industries is tk. 76,500 million. Currently, the Bangladeshi pharmaceutical companies are exporting drugs in many developed and developing countries in the rest of the world and earning huge foreign currency for the Bangladeshi exchequer.

Hence, the sustainable profitability of the pharmaceutical industries of Bangladesh is a prime concern to the related parties like the company owners, regulators and the internal customers like the employees is one of the major concerns. Profit in the accounting sense tends to become a long term objective which measures not only the success of a product, but also of the development of the market for it (Nimalathasan, 2009). Profit is an absolute measure of earning capacity, while profitability is relative measure of earning capacity. Banarjee (1976) defined profitability as the profit earning capacity of a product, process, plant or undertaking.

The present study aims to explore the determinants of the profitability of the pharmaceutical industry of Bangladesh. After the banking industry, the pharmaceutical industry is the second largest white-color job creating industry in Bangladesh. To be profitable and to maintain the sustainable profitability of the firms is necessary for the welfare of the employers and also for the employees. In order to do such, they must know definitely the factors contributing the profitability of their business operations. Among the contributing factors, some may be from the company level and some may be from the macroeconomic level variables. We studied both firm and macroeconomic level variables and showed their impact, either positive or negative on the firm profitability. This study, in this sense, will be very interesting to the company level decision makers and to the other stakeholders of this industry.

The remaining part of the paper has been organized as the literature in part 2, and then in part 3 , we narrated the sample selection and the sources of data. In part 4, we illustrated the econometric model and in part 5 we present our 
findings and analysis of the regression output. Finally, in part 6, we concluded our paper with some policy recommendations. Then we moved to give the reference section and the appendix seemed relevant to our study.

\section{Literature}

In this paper, we studied the determinants of the profitability of the pharmaceutical industry of Bangladesh. We found very few studies in the past studied the determinants of the profitability of the pharmaceutical industry of Bangladesh in a comprehensive manner. In the past literature, we found many studies on the profitability of the other industries like bank, non-bank, insurance companies and others both in the national and in the global levels.

Following Short (1979) and Bourke (1989) a number of researchers studied banking profitability determinants using single linear model of either cross country or on country specific banking data. Among others, Molyneux and Thornton (1992) examined the determinants of banks profitability operating in 18 European countries over the period 1986-1989 and Pasiouras et al. (2007) studied that of 15 EU countries. On the other hand, panel studies of Athanasoglu et al. (2008) and Dietrich et al. (2011) are on the banking profitability of Greek and Switzerland respectively. However, no single study was out of criticism due to insufficiently selection of variables or failure to implement the appropriate econometric methodology counting for profit persistency of banks (Athanasoglu, 2008). In the near past Islam and Nishiyama (2016) studied the determinants of the profitability of the banks of the South Asian countries using firm specific, industry specific and the macroeconomic specific variables.

Jayasuriya (1991) studied that the infrastructure development and the deployment of the trained manpower are essential elements for the profitability of the pharmaceutical companies in Sri Lanka. Kremer (2002) found that pharmaceuticals have greatly improved health in developing countries but many people in developing countries do not obtain even inexpensive pharmaceuticals and little research and development expenditures by the firms.

In case the pharmaceutical industry of Bangladesh, Hoq et al. (2013) analyzed the pharmaceutical sector of Bangladesh. Using SWOT (strength, weakness, opportunity and the threat) framework, they found the sales and marketing challenges are the major hindrances of the profitability. Habib and Alam (2011) explored that some major problems of marketing, export, production and operations are challenges of growth of the industry in Bangladesh. Bhuiyan et al. (2011) found the foreign investment could be necessary for the prosperity of the pharmaceutical industry of Bangladesh. Among others, Nimalathasan (2009) studied the profitability of 2 listed pharmaceutical companies of Bangladesh. But they studied the profitability of the two pharmaceutical companies in descriptive manner.

The present study seems the first to explore the profitability of the pharmaceutical industry of Bangladesh comprising the firm level and the macroeconomic level data. Another distinguishing feature of the study is, we used the panel regression and our sample size is also relatively larger.

\section{Sample and Data}

The current paper used 10 years panel data starting from 2007 to 2016 of 20 listed companies with the Dhaka Stock Exchange (DSE) ltd. We collected the firm level data from the secondary sources mainly from the websites of the sample companies. The macroeconomic data of the rate of inflation and the growth rate of GDP have been collected from the Bangladesh Bank websites.

We have determined the size of the sample using the following formula:

$$
n=\frac{Z^{2} p q}{e^{2}}
$$

Where,

$\mathrm{n}=$ Size of the sample

$\mathrm{z}=$ the value of standard vitiate at a given confidence level and to be worked out from table showing area under normal curve.

$\mathrm{p}=$ Sample proportion, $\mathrm{q}=1-\mathrm{p}$

$\mathrm{e}=$ acceptable error limit

If, $\mathrm{z}=1.64$ at $10 \%, \mathrm{p}=0.5$, so $\mathrm{q}=0.5$, then

The sample size, $n=\frac{Z^{2} p q}{e^{2}}$ or, $n=\frac{(1.64)^{2} * 0.5 * 0.5}{0.034^{2}}$ or $n=20.02$ 
Table 1 in the following describes the summary statistics of the variables have been used in the study of the profitability of the pharmaceutical industry of Bangladesh.

Table 1. Summary statistics of the variables included in the study

\begin{tabular}{lllll}
\hline Variable & Mean & Std. Dev. & Min & Max \\
\hline Sales to Total Assets & 0.09309 & 0.6343 & 0.01179 & 3.0217 \\
\hline Totaloperating income to Total Assets & 0.0895 & 0.0480 & 0.0120 & 0.2356 \\
\hline Return on Equity & 0.1692 & 0.0955 & 0.0100 & 0.3715 \\
\hline Operating Cost to Total Assets & 0.4640 & 0.7342 & 0.0239 & 4.3563 \\
\hline Log of Total Assets & 9.0727 & 1.2940 & 6.3008 & 11.6949 \\
\hline Total Liabilities to Total Assets & 0.5242 & 0.3787 & 0.0659 & 2.4913 \\
\hline Rate of inflation & 0.0822 & 0.0199 & 0.0592 & 0.1230 \\
\hline GDP growth rate & 0.0620 & 0.0055 & 0.0505 & 0.0711 \\
\hline
\end{tabular}

The Table above illustrates that the mean value of the return on asset (ROA) is around 9 percent. Major portion of the firms' operating income went away in the form of operating cost as seen the operating cost is around 46 percent. The sample firms also having total liabilities almost more than half of their value of total assets. From Table 1 above, we see the average GDP growth rate was over 6 percent during the sample period.

\section{Econometric Model}

In the study of the determinants of the profitability of the pharmaceutical industry of Bangladesh, we viewed that both the firm specific and the macroeconomic specific variables affect the profitability of the companies. Profitability $(\pi)$ of every firm (i) at time (t) will be affected by some other firm specific variables and the growth rate of GDP and the rate of inflation in the macroeconomic level. Thus, the general model to be estimated as follows:

$$
\begin{gathered}
\Pi_{\mathrm{it}}=\mathrm{c}+\sum_{\mathrm{j}=0}^{\mathrm{J}} \beta_{\mathrm{j}} \mathrm{X}_{\mathrm{it}}^{\mathrm{j}}+\sum_{\mathrm{m}=0}^{\mathrm{M}} \beta_{\mathrm{m}} \mathrm{X}_{\mathrm{it}}^{\mathrm{m}}+\varepsilon_{\mathrm{it}} \\
\varepsilon_{\mathrm{it}}=v_{\mathrm{i}}+\mathrm{v}_{\mathrm{it}}
\end{gathered}
$$

Where, $\Pi_{i t}$ is the profitability of bank $\mathrm{i}$ at time $\mathrm{t}$ and measured at parameter $R O A_{i t}$ with $\mathrm{i}=1, \ldots . \mathrm{N}, \mathrm{t}=1, \ldots \ldots, \mathrm{T}$ and $\mathrm{c}$ is a constant term. The superscripts $j$ and $m$ of $\mathrm{X}_{\mathrm{it}}$ denote the firm specific and macroeconomic specific determinants respectively. $\varepsilon_{\mathrm{it}}$ is the disturbance with $v_{\mathrm{i}}$ the unobserved firm-specific effect and $v_{i t}$ the idiosyncratic error. The error components of the regression model also distributed as $v_{\mathrm{i}} \sim \operatorname{IIN}\left(0, \sigma_{v}^{2}\right)$ and independent of $v_{i t} \sim \operatorname{IIN}\left(0, \sigma_{v}^{2}\right)$.

To estimate the regression output of the equation (1) we selected the random effect model. We ran the Hausman test model specification test that favored the use of random effect model over fixed effect. Random effect model is used in the analysis of hierarchical or panel data when the assumption is that there will be no fixed effect that is the regressors to be individual-invariant (Baltagi, 2001). The variation across the entities is assumed to be random and uncorrelated with the independent variable and any unobserved individual effect. The random effects model is:

$$
\begin{gathered}
\mathrm{Y}_{\mathrm{it}}=\alpha+\beta X_{\mathrm{it}}+u_{\mathrm{i}}+\varepsilon_{\mathrm{it}} \\
\mathrm{Y}_{\mathrm{it}}=\alpha+\beta X_{\mathrm{it}}+\mu_{\mathrm{it}}
\end{gathered}
$$

Assumptions of Random Effect Model are:

- $\quad$ Ui and cit are mutually uncorrelated.

- $\quad \mathrm{E}[\mathrm{Xit}, \boldsymbol{\varepsilon i t}]=0$, and if this condition holds then the model is called Random Effect Model.

In the later step of our econometric model, we tested the dataset for autocorrelation both by using the autocorrelation matrix (see the appendix Table 1) and the variance inflation factor (VIF) (see the appendix Table 2). Both the test 
output showed there is no autocorrelation problem in the panel dataset. Thus we proceed to run our regression equation using the variables have been stated in Table 2 in the following:

Table 2. Description of variables used in the study

\begin{tabular}{lll}
\hline Variables & Description & Expected effect \\
\hline Dependent variables & Net income over average total assets (ROA) & \\
\hline Profit(П) & & \\
\hline Independent variables & & + \\
\hline (a). Bank-specific variables & Sales to Total Asset ratio & + \\
\hline Sales & Total operating income over total asset & + \\
\hline Total operating income & Operating income to total equity & + \\
\hline Return on equity & Operating cost to total asset & - \\
\hline Operating cost & Log of total asset & $+/-$ \\
\hline Size of the firm & Total liabilities to total asset & $+/-$ \\
\hline Total liabilities & Annual rate of inflation $(\%)$ & + \\
\hline (b). Macroeconomic-specific variables & \\
\hline Rate of inflation & Real economic growth rate as a $\%$ change in GDP & \\
\hline GDP growth rate &
\end{tabular}

In this study, we used the return on asset (ROA) as the dependent variable. ROA has emerged as the key ratio for the evaluation of a firm's profitability and has become the most common measure in the literature (Golin, 2001). We have taken five firm specific and two macroeconomic specific variables as the independent variables. The firm specific variables are the sales, total operating income, return on equity, operating cost, firm size and the total liabilities. Our initial hypothesis regarding sales is that, holding others remaining constant, increase in sales will increase the profitability of the firm. Regarding operating cost, our hypothesis is just opposite in case of sales revenue. Size of the firm may have either positive or negative effect on the profitability of the company.

Initial hypothesis regarding the macroeconomic specific variables are that, the rate of inflation and the GDP growth rate may not have any effect on the firm profitability. We viewed such as the pharmaceutical products may not be growth or price sensitive. People buy the pharmaceutical products to save their lives irrespective of their income or the quality of life.

\section{Findings and Analysis}

We have estimated our base regression of the equation (1) using the econometric software of stata. Initially we estimated the regression equation using both firm and macroeconomic specific variables. To see the robustness of the model estimation, we ran another model using only firm specific variables. The regression output has been presented in the Table 3 in the following.

The model-1 output in the Table 3, illustrates that sales having negative effect on the firm profitability. Though the beta coefficient of sales is insignificant at 5 percent level of significance, the result is just opposite of our initial hypothesis. Total operating income found to support our initial assumption that, holding others remaining constant, total operating profit will positively affect the firm profitability. We found the coefficient of total operating profit is statistically significant in both the models. 
Table 3. The determinants of the profitability of the pharmaceutical industry of Bangladesh

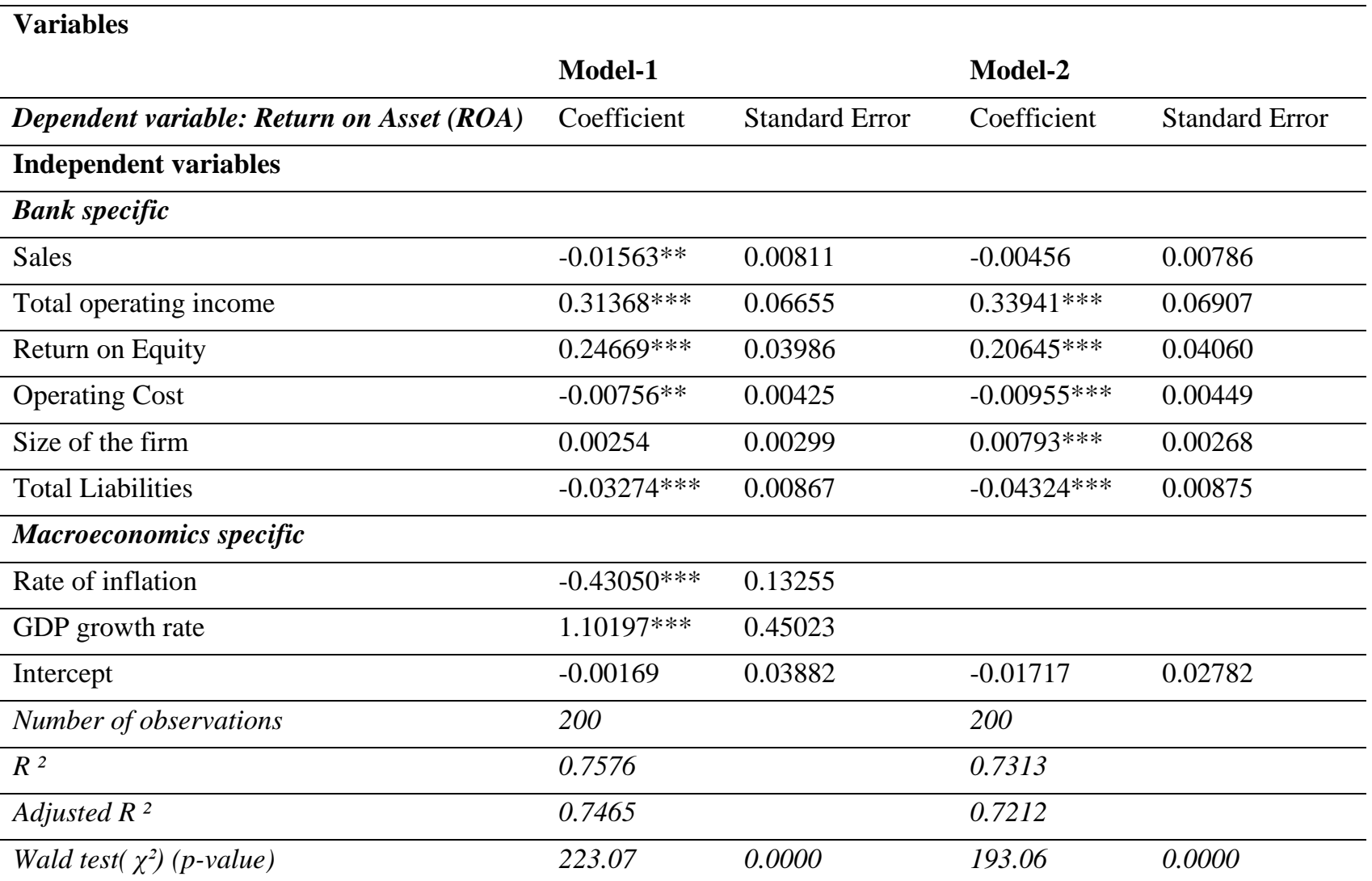

Note: The Table reports the regression output from Random Effect (RE) estimation of the determinants of profitability. Coefficients that are significantly different from zero at the $1 \%, 5 \%$ and $10 \%$ level are marked with $* * *$, $* *$, and * respectively. Wald test is the test for the goodness of fit of the model estimator.

Size of the firm variable emerged to be significantly affecting the profitability of the pharmaceutical firms in Bangladesh only in model-2; that is when we considered only the firm specific variables. As expected, the liabilities of the firm, negatively affect the profitability. As we found, for every one percent increase in liability will reduce the firm profitability by 3.27 percent. We also found the expected sign of the coefficient of the operating cost variable. I operating cost of a firm increase by one percent then the profitability of that firm reduce by around 8 basis point.

The regression output shows that the rate of inflation inversely affects the profitability of the pharmaceutical companies in Bangladesh. This may happen as an increase in the rate of inflation decrease the purchasing power of the customers. And that may negatively affect the sales revenue and thus the profitability of the firms. Regarding the GDP growth rate, we found this positively affect the firm's profitability. The justification is that, GDP growth rate fosters the business prospects and like many other industries, the pharmaceutical industry also can do business with prosperity.

\section{Policy Implications and Conclusion}

The present paper investigates the determinants of the profitability of the pharmaceutical industry of Bangladesh. Using the 10 year panel data of 20 leading and listed pharmaceutical companies in Bangladesh, we estimated the regression. In the regression equation, we included both firm specific variables and the macroeconomic variables. Among the firm level variables, we found that operating income, return on equity and firm size positively affects the profitability of the pharmaceutical firms. We found operating cost and the liabilities of the firm inversely affect the profitability.

Rate of inflation which has been used as the proxy of macroeconomic variable, inversely affect on firm profitability. The macroeconomic variable i.e., the growth rate of GDP has positive effect on the firm profitability. The coefficient of rate of inflation and the GDP growth rate, found to be statistically significant. 
Regarding the policy implication, the firm managers may use the research outcome in order to take important decisions related to maximize their business objective i.e., to maximize profit and to remain profitable. Policy makers in the state level may also use the regression result as the macroeconomic variables also found significantly affecting the profitability of an important industry within the economy.

The paper also has some future direction of research. The research and development (R \& D) expenditures, quality of the work force, tax levels among many variables may be included in the regression and would be found their effect and deterministic capacity on the profitability of the pharmaceutical industry in Bangladesh and also in case in the rest of the World.

\section{References}

Athanasoglu, P., et. al. (2008). Bank specific, industry specific and macroeconomic determinants of bank profitability. Journal of International Financial Markets, Institutions and Money, 18, 121-136. https://doi.org/10.1016/j.intfin.2006.07.001

Baltagi, B. H. (2001). Econometric Analysis of Panel Data (2nd ed.). John Wiley \& Sons, Chichester.

Banarjee. (1976). Cost Accounts. The World Press Pvy. Ltd. Calcutta.

Bashar, S. M., \& Islam, M. I. (2014). Determinants of profitability in the pharmaceutical industries of Bangladesh. Journal of State University of Bangladesh, 5, 56-76.

Bhuiyan, M. A. R., \& Moniruzzaman, S. S. (2011). Analysis of pharmaceutical industries of Bangladesh. Bangladesh Research Publication Journal, 5, 142-156.

Habib, M. A., \& Alam, M. Z. (2011). Business analysysis of pharmaceutical firms in Bangladesh: problems and prospects. Journal of Business Technology, 6, 61-77.

Hausman, J. A. (1978). Specification tests in econometrics. Econometrica, 46, 1251-1271. https://doi.org/10.2307/1913827

Hoq, M. R., Ahsan, M. A., \& Tabassum, T. A. (2013). Study on SWOT analysis of pharmaceutical industries: Bangladesh context. Global Disclosusure of Economics and Business, 2, 133-141.

Hossain, M. M., \& Shoaib, S. M. (2014). Role of pharmaceutical sector in the national economy of Bangladesh. W. $J$. Pharm. Pharmaceut. Sci., 3, 951-960.

Islam, S., \& Nishiyama, S. (2016a). The determinants of bank net interest margins: A panel evidence from South Asian countries. Research in International Business and Finance, 37, 501-514. https://doi.org/10.1016/j.ribaf.2016.01.024

Islam, S., \& Nishiyama, S. (2016b). The determinants of bank profitability: Dynamic panel evidence from South Asian countries. Journal of Applied Finance and Banking, 6(3), 77-97.

Iyer, N. (1995). An evaluation of the financial performance of public sector enterprises of Kerala. University of Kerala.

Jesmin, S. (2016). Future prospects and barriers of pharmaceutical industries in Bangladesh. Bangladesh Pharmaceutical Journal, 19(1), 53-57. https://doi.org/10.3329/bpj.v19i1.29239

Molyneux, P., \& Thornton, J. (1992). Determinants of European Bank Profitability: A Note. Journal of Banking and Finance, 16(6), 1773-1778. https://doi.org/10.1016/0378-4266(92)90065-8

Nimalathasan. (2009). Profitability of listed pharmaceutical companies in Bangladesh: An inter and intra comparison of Ambee and IBN Sina companies Ltd. Annals of University of Bucharest, 3, 139-148.

Short, B. (1979). The relation between commercial bank profit rates and banking concentration in Canada, Western Europe and Japan. Journal of Banking and Fiance, 3(3), 209-219. https://doi.org/10.1016/0378-4266(79)90016-5

Smirlock, M. (1985). Evidence on the (non) relationship between concentration and profitability in banking. Journal of Money, Credit, and Banking, 17(1), 69-83. https://doi.org/10.2307/1992507

Wooldridge, J. M. (1995). Score diagnostics for linear models estimated by two stage least squares. In C. R. Rao, G. S. Maddala, P. C. B. Phillips, \& T. N. Srinivasan (Eds.), Advances in Econometrics and Quantitative Economics (pp. 66-87). Oxford: Blackwell. 


\section{Appendix}

Table A1. Correlation matrix of the variables* included in the study

\begin{tabular}{|c|c|c|c|c|c|c|c|c|}
\hline Variables & salesta & roa & roe & octa & lnta & tlta & inf & gdp \\
\hline salesta & 1 & & & & & & & \\
\hline roa & -0.0009 & 1 & & & & & & \\
\hline roe & 0.4412 & 0.6167 & 1 & & & & & \\
\hline octa & 0.5705 & -0.3119 & 0.0971 & 1 & & & & \\
\hline lnta & -0.5852 & 0.234 & -0.1091 & -0.3316 & 1 & & & \\
\hline tlta & 0.5041 & -0.3022 & 0.1812 & 0.5164 & -0.2829 & 1 & & \\
\hline inf & -0.0112 & -0.2326 & 0.0248 & 0.0566 & -0.2869 & 0.1592 & 1 & \\
\hline gdp & -0.0456 & 0.0494 & -0.1651 & -0.0879 & 0.185 & -0.1153 & 0.0329 & 1 \\
\hline
\end{tabular}

* Stata output and for the details of the names of the variables, refer to Table 1 in the main text

Table A2. Variance Inflation Factor (VIF) of the variables included in the study

\begin{tabular}{llllllllll}
\hline Variable & salesta & roa & roe & lnta & octa & tlta & inf & gdp & Mean \\
\hline VIF & 3.54 & 2.34 & 2.23 & 2.08 & 1.75 & 1.65 & 1.27 & 1.16 & 2 \\
\hline 1/VIF & 0.282228 & 0.42644 & 0.448453 & 0.481176 & 0.570605 & 0.606544 & 0.786064 & 0.864871 & \\
\hline
\end{tabular}

